\title{
EVALUATION OF THE HEAD MULTISLICE COMPUTED TOMOGRAPHY SCAN IN EMERGENCY DEPARTMENT
}

\author{
Dijana Zadravec ${ }^{1}$, Tomislav Gregurić ${ }^{1}$, Mia Smoljan ${ }^{1}$, Matej Mustapić ${ }^{1}$, Gordana Miličić \\ Andrijana Jović ${ }^{1}$, Danijela Rubil ${ }^{1}$, Daniela Tomasović ${ }^{1}$ and Vanja Bašić Kes ${ }^{3}$
}

${ }^{1}$ Clinical Department of Diagnostic and Interventional Radiology, Sestre milosrdnice University Hospital Center; ${ }^{2}$ Department of Orthopedics, Zagreb Children's Hospital; ${ }^{3} \mathrm{Clinical}$ Department of Neurology,

Sestre milosrdnice University Hospital Center, Zagreb, Croatia

\begin{abstract}
SUMMARY - The aim of the study was to examine the prevalence of head injuries, acute stroke and brain tumors obtained from computed tomography (CT) scans in the emergency department (ED) during a one-year period. We also assessed the potential effect of seasons on the occurrence of stroke, head trauma and tumors found on CT scans, expressed in monthly intervals. This retrospective review included all patients that underwent emergency head CT from the hospital database. A total of 3888 head CT examinations were performed in adult patients presenting to ED and $1424 \mathrm{CT}$ scans had at least one pathologic finding meeting diagnostic criteria for the study. Of the total number of CT scans analyzed, acute stroke was identified in 552 (14.19\%), head trauma in 660 (16.97\%), and brain tumor in $212(5.45 \%)$ patients. Head trauma was more commonly found in males $(n=465$, $70.45 \%)$ than in females $(\mathrm{n}=195,29.54 \%)$. Acute stroke was slightly more common in males than in females. Brain tumors were more frequently found in female patients. There were monthly variations in the number of head injuries and acute stroke diagnosed during the study period. Men and elderly patients were found to account for the greatest number of traumatic head injuries and therefore are at the highest risk of possible brain injury.

Key words: Computed tomography; Emergency service, hospital; Craniocerebral trauma; Stroke; Brain neoplasms
\end{abstract}

\section{Introduction}

Computed tomography (CT) examination of the head has become a key diagnostic tool in the assessment of patients with serious head injury or cerebrovascular disease in the emergency department (ED). $\mathrm{CT}$ is widely available, enables rapid imaging, and helps establish correct diagnosis.

Trauma is one of the most frequent indications for emergency neuroimaging. Cranial trauma demands

Correspondence to: Assist. Prof. Dijana Zadravec, MD, PhD, Clinical Department of Diagnostic and Interventional Radiology, Sestre milosrdnice University Hospital Center, Vinogradska c. 29, HR-10000 Zagreb, Croatia

E-mail: zadravec@sfzg.hr

Received April 8,2016, accepted March 15, 2017 accurate and rapid assessment of the brain and skull injuries. In patients with head trauma, CT evaluation advantages include sensitivity to bone injuries and acute hemorrhage, widespread availability, short scanning time, and compatibility with medical devices.

Stroke is the second leading cause of death worldwide and the leading cause of adult disability ${ }^{1}$. Imaging plays a critical role in the evaluation of patients with suspected acute stroke. The primary goal is to distinguish between hemorrhagic and ischemic stroke ${ }^{2}$. Early detection of stroke etiology is crucial for stroke management. Neuroimaging is a standard procedure for all patients with suspected stroke, which provides diagnostic information needed for choosing the most appropriate therapy. 
Remarkable increase in the number of patients attending EDs is noted ${ }^{3}$. Accordingly, there has been an increase in emergency CT examinations performed ${ }^{4,5}$. The aim of the present study was to examine the prevalence of traumatic head injuries, acute stroke and intracranial tumors obtained from CT scans during a one-year period. We also assessed the potential effect of seasons on the occurrence of stroke, head trauma and brain tumors found on CT scans, expressed in monthly intervals.

\section{Patients and Methods}

This retrospective study was conducted at the Clinical Department of Diagnostic and Interventional Radiology, Sestre milosrdnice University Hospital Center. We performed retrospective review from the hospital picture archiving and communication system (PACS) database for all patients who underwent head CT in the ED from January 2013 to December 2013. Requests for CT examinations were indicated by ED physicians or by residents after consulting the attending physicians. Data regarding patient characteristics (age and gender) and head CT reports were collected from the electronic database. All CT scans were interpreted by board-certified radiologists at the radiology workstations.

Pathologic CT findings were classified into three groups of diseases: head trauma (patients with skull fractures, traumatic subarachnoid hemorrhage (SAH), traumatic intracerebral hematoma, cerebral contusions/lacerations, epidural hematoma, acute subdural hematoma or chronic/mixed subdural hematoma), acute stroke (patients with acute brain ischemia, subacute ischemia, non-traumatic $\mathrm{SAH}$ or non-traumatic intracerebral hematoma), and brain tumors. All other CT findings were defined as nonsignificant (patients with chronic pathologic CT findings such as chronic brain infarction, encephalomalacia, vasculopathy or gliosis). Total number of pathologic findings was assessed, not only total number of patients, as some patients had more than one pathologic finding seen on their CT scans. Descriptive statistical analyses were performed and trends of CT pathologic findings during the year were evaluated, as well as distribution by age and gender. Age categories were 18-29 years, 3039 years, $40-49$ years, 50-59 years, 60-69 years, 70-79 years and $\geq 80$ years. Monthly variations in the preva- lence of head trauma, acute stroke and brain tumors were analyzed. We excluded patients who were not treated in the ED and were younger than 18 years.

Head CT scans were obtained using a Siemens Sensation 16-slice CT scanner with contiguous axial mode scanning and 1-3 mm slice thickness. All scans were performed with soft tissue window (H31s medium smooth) and bone window (H60s) settings.

\section{Results}

During the period from January 2013 to December 2013, a total of 3888 head CT examinations were performed in patients admitted to ED and $1424 \mathrm{CT}$

\section{Table 1. Demographic characteristics of study groups}

\begin{tabular}{|l|l|l|l|}
\hline CT finding & $\mathrm{N}$ & Male, $\mathrm{n}(\%)$ & Female, $\mathrm{n}(\%)$ \\
\hline Acute stroke & 552 & $282(51.08)$ & $270(48.91)$ \\
Head trauma & 660 & $465(70.45)$ & $195(29.54)$ \\
Intracranial tumor & 212 & $92(43.39)$ & $120(56.60)$ \\
\hline
\end{tabular}

$\mathrm{CT}=$ computed tomography

Table 2. Distribution of radiologic CT findings in patients with head trauma, acute stroke and intracranial tumors

\begin{tabular}{|l|l|l|}
\hline Trauma - CT finding (N=1469) & $\mathrm{n}$ & $\%$ \\
\hline Skull fracture & 339 & 23.07 \\
Traumatic SAH & 321 & 21.85 \\
Traumatic intracerebral hematoma & 70 & 4.76 \\
Cerebral contusion/laceration & 222 & 15.11 \\
Epidural hematoma & 68 & 4.63 \\
Acute subdural hematoma & 356 & 24.23 \\
Chronic/mixed subdural hematoma & 93 & 6.33 \\
\hline Acute stroke - CT finding $(\mathrm{N}=597)$ & $\mathrm{n}$ & $\%$ \\
\hline Acute ischemia & 286 & 47.90 \\
Subacute ischemia & 66 & 11.06 \\
Non-traumatic SAH & 101 & 16.92 \\
Intracerebral hematoma & 144 & 24.12 \\
\hline Tumor - CT finding $(\mathrm{N}=212)$ & $\mathrm{n}$ & $\%$ \\
\hline Primary brain tumor & 23 & 10.84 \\
Meningioma & 56 & 26.41 \\
Metastasis & 45 & 21.22 \\
Unclassifed tumor & 88 & 41.50 \\
\hline
\end{tabular}

$\mathrm{CT}=$ computed tomography; $\mathrm{SAH}=$ subarachnoid hemorrhage 


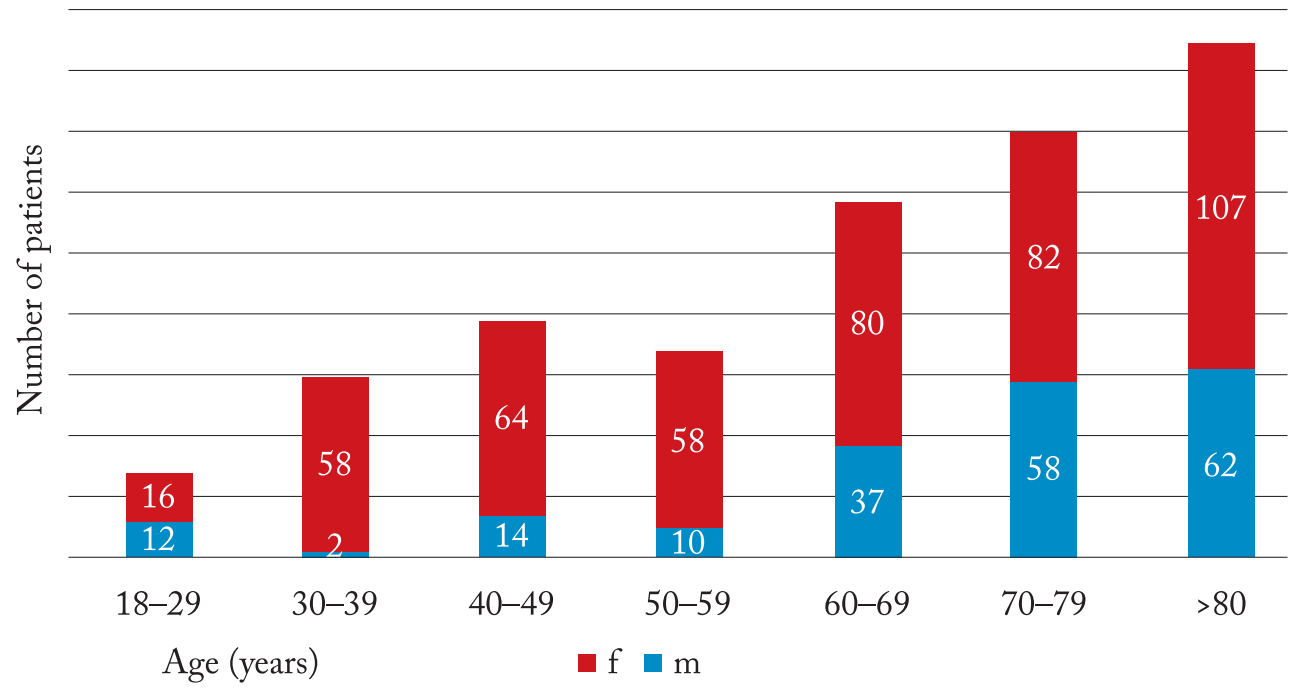

Fig. 1. Distribution of head trauma according to age and gender.

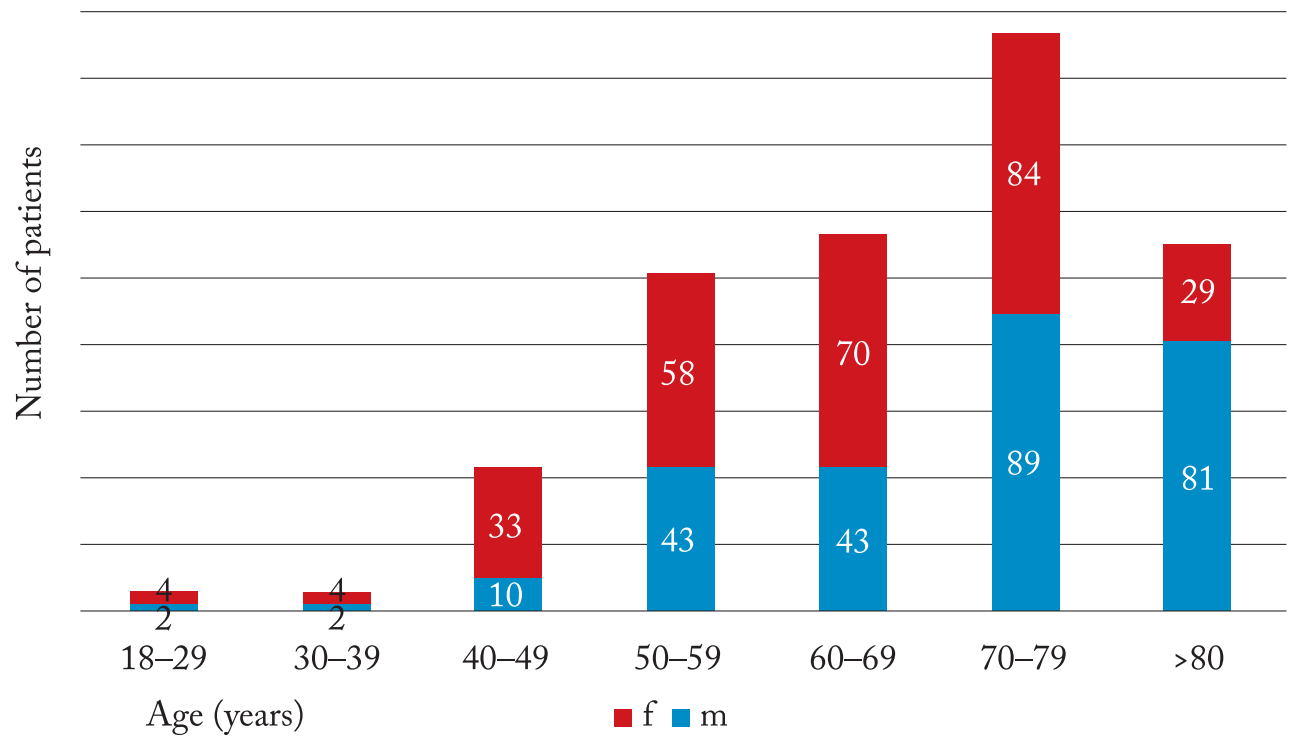

Fig. 2. Distribution of acute stroke according to age and gender.

scans had pathologic findings meeting diagnostic criteria for the study. Of the total number of CT scans analyzed, acute stroke was identified in 552 (14.19\%), head trauma in 660 (16.97\%) and brain tumor in 212 (5.45\%) patients. Number and percentage of patients in each study group and their gender distribution are summarized in Table 1 . Head trauma was more frequently found in males $(n=465,70.45 \%)$ than in females $(n=195,29.54 \%)$. Acute stroke was slightly more common in males $(\mathrm{n}=282,51.08 \%)$ than in females $(\mathrm{n}=270,48.91 \%)$. Brain tumors were more often found in female $(\mathrm{n}=120,56.60 \%)$ than in male patients $(\mathrm{n}=92$, 43.39\%).

Patients who presented with head trauma were categorized according to injury diagnosed on CT scan. Table 2 shows the proportion of traumatic head injuries detected in trauma patients. Of the total number of traumatic head injuries, the most common injury 


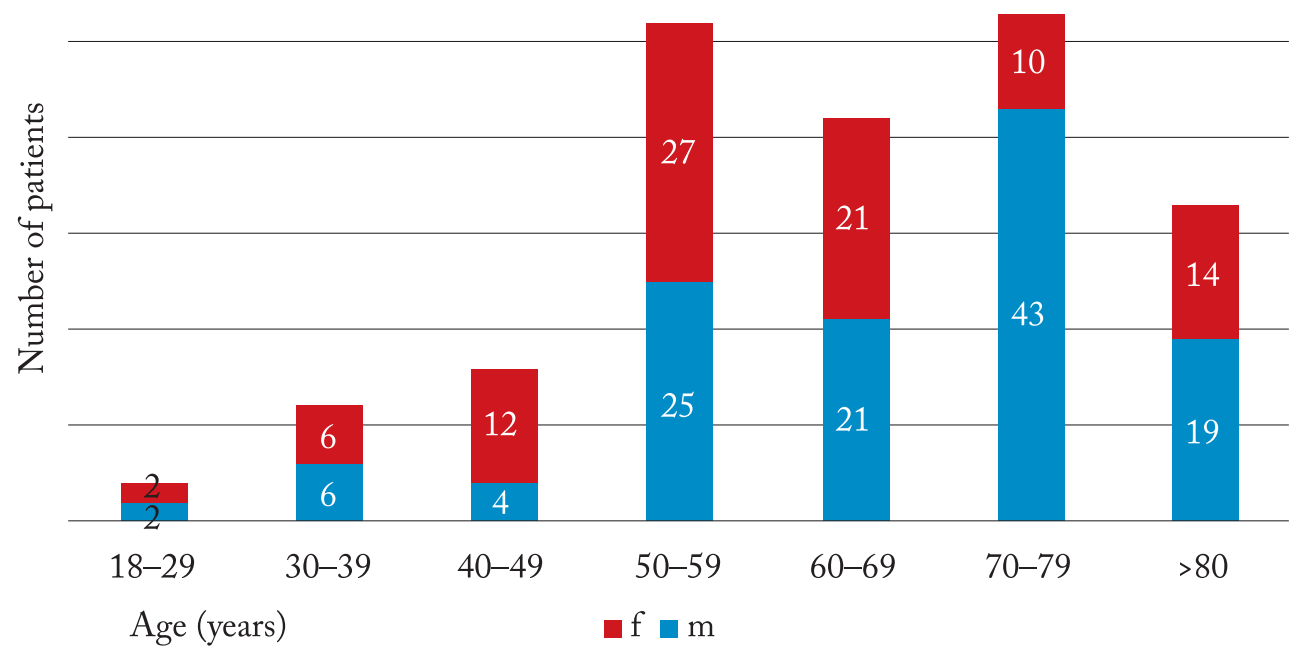

Fig. 3. Distribution of tumors according to age and gender.

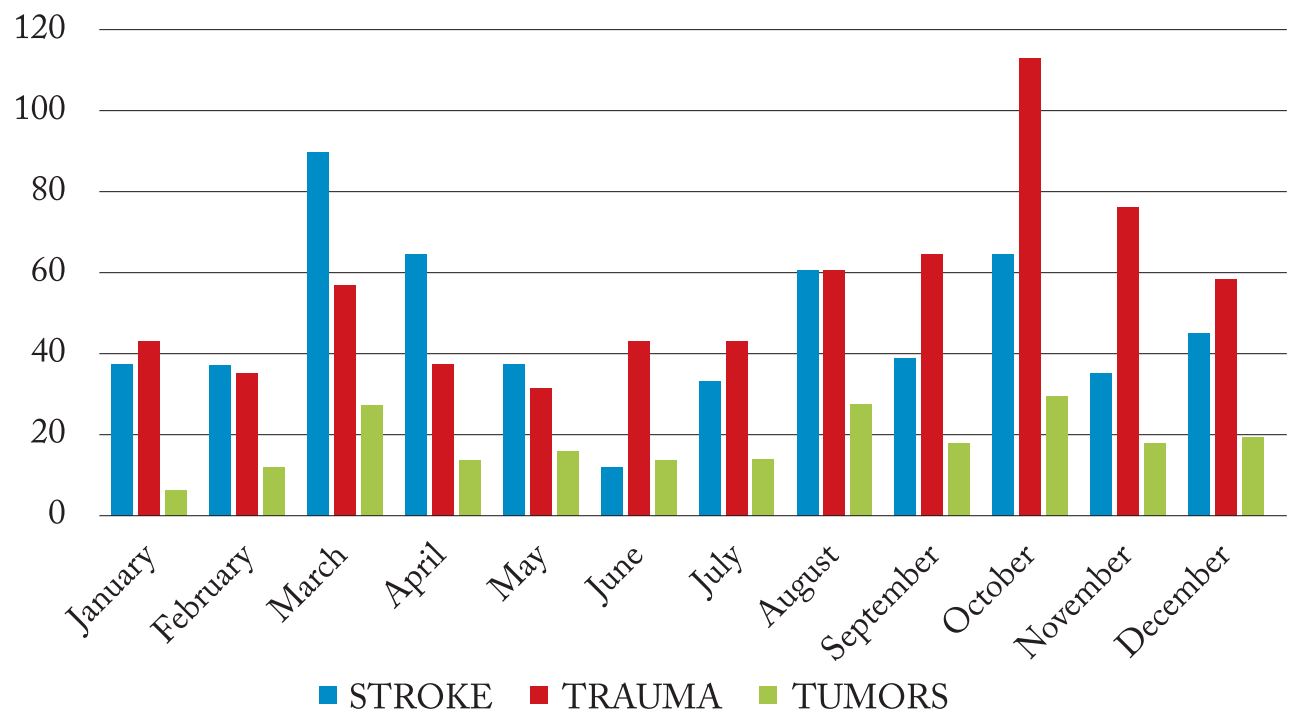

Fig. 4. Distribution of head trauma, acute stroke and tumors according to months.

found on CT scan was acute subdural hematoma $(\mathrm{n}=356,24.23 \%)$. Skull fracture was found in 339 (23.07\%) patients. Traumatic SAH was found in 321 $(21.85 \%)$ cases of traumatic head injuries, followed by cerebral contusion/laceration ( $\mathrm{n}=222,15.11 \%)$. Chronic/mixed subdural hematoma was documented in $93(6.33 \%)$ cases of traumatic head injuries. The least common traumatic head injuries were traumatic intracerebral hematoma $(\mathrm{n}=70,4.76 \%)$ and epidural hematoma ( $n=68,4.63 \%)$. Distribution of head trauma according to age and gender is shown in Figure 1.
Across all age groups, head injuries were more common in males than in females. In addition, the highest prevalence of head injuries was detected in the older age groups of patients.

Distribution of stroke subtypes detected on CT scans is presented in Table 2. Radiologic diagnosis of acute cerebral ischemia was the most common type of acute stroke ( $\mathrm{n}=286,47.9 \%)$. Non-traumatic intracerebral hematoma was found in 144 (24.12\%) cases of acute stroke. Non-traumatic SAH was identified in $101(16.92 \%)$ and subacute ischemia in 66 (11.06\%) 
cases of acute stroke. Distribution of acute stroke subtypes according to age and gender is shown in $\mathrm{Fi}^{-}$ gure 2. As illustrated in Figure 2, the prevalence of stroke increased continuously until the age of 80 for both male and female patients. After 80 years of age, the prevalence of stroke began to decline for both sexes.

The most common brain tumor by radiological assessment was an unclassified tumor, which accounted for $41.50 \%(n=88)$ of all diagnosed brain tumors. The prevalence of brain tumors identified on $\mathrm{CT}$ is shown in Table 2. Meningioma accounted for $26.41 \%(n=56)$ of all diagnosed intracranial tumors, whereas metastases accounted for $21.22 \%(n=45)$ of all tumors. Primary brain tumor was found in $10.84 \%(n=23)$ of patients. Most tumors were found in patients between 50 and 79 years of age. Distribution of brain tumors according to age and gender is shown in Figure 3.

Monthly variations in the prevalence of head trauma, acute stroke and brain tumors over the one-year period are presented in Figure 4. The highest prevalence of acute stroke was recorded in March, followed by April and October. The lowest prevalence of acute stroke was found in June and July. There were monthly variations in the number of diagnosed head injuries, with the peak in October, whereas May showed the lowest prevalence of head injuries. As shown in Figure 4 , there were no specific monthly peaks for brain tumors.

\section{Discussion}

Utilization of emergency CT examinations has increased dramatically during the last few decades ${ }^{5}$. CT imaging is the most important part of diagnostic assessment for patients with trauma. Imaging is useful for diagnosing the type and severity of CT abnormalities related to head injury. CT is also valuable as a tool to select patients who require immediate surgical treatment versus those who require in-hospital observation and medical management. There is an increase in the use of CT for injured patients ${ }^{6}$. Head CT related to trauma is also more common than $\mathrm{CT}$ of other body areas ${ }^{6}$. More than 1.7 million traumatic brain injuries (TBI) occur in the United States each year and an increase in the number and rate of head trauma has been noted in the last decade ${ }^{7,8}$. Traumatic brain injury is an important public health problem throughout the world, with high rates of ED visits, hospitalizations and deaths ${ }^{9,10}$. A meta-analysis by Frost et al. using 15 studies originating from developed countries found a TBI prevalence of $12 \%$ in general population ${ }^{11}$. Our study found approximately double increase in the number of $\mathrm{CT}$ examinations performed in $\mathrm{ED}$, when compared with a previous study carried out in our Department during the 2001-2002 period $^{12}$.

Acute subdural and epidural hematomas are among the most common causes of mortality and disability resulting from head injury ${ }^{13}$. In our study, subdural hematoma was the most common CT finding in patients with head trauma, which is in concordance with other study results, although the rates of other head injury types vary from study to study ${ }^{14,15}$. Špero et al. found head trauma in $28.93 \%$ of cases with pathologic emergency brain CT findings, including skull fractures ${ }^{12}$. Similar prevalence (29.4\%) of head injuries was identified in our study. Our study confirmed the results of many previous reports on the head injury rates to be higher in males than in females in all age groups ${ }^{7,11}$. These findings suggest that male gender is a risk factor for traumatic brain injury. Previous studies have shown different head trauma rates related to age as a result of different injury mechanisms that occur in different age groups ${ }^{16}$. Children and young adults sustain peak rates in motor vehicle and sports-related head trauma, whereas peak rates in fall-related head trauma occur in the oldest and youngest segments of the population. Our study showed the highest prevalence of head injuries in older age subgroups, with a higher prevalence of head trauma in patients over 60 years of age. Pediatric patients with head trauma were not included in our study.

In addition to the well-known classic risk factors for stroke (such as high blood pressure, smoking, elevated blood cholesterol levels and body mass index), age, sex and regional/population factors have been recognized as relative risks for stroke ${ }^{17}$. In developed countries, the average stroke occurring age is around 73 years, reflecting the older age structure of the countries, whereas in less developed countries stroke occurs in younger population ${ }^{18,19}$. In our study, acute stroke was most frequently found in patients aged 70-79 years and was slightly more common in males than in females, which was also demonstrated by several previous studies, but this issue is still controversial ${ }^{19-21}$. Our study found ischemia as the major cause of acute 
stroke, while only a lower proportion of hemorrhagic strokes was detected. A similar distribution of pathologic stroke types is found in the literature ${ }^{22}$. Evidence for seasonal variation in stroke incidence is still controversial. Some previous researches connected stroke incidence to weather, seasonal effects, and air pollu$\operatorname{tion}^{23,24}$. While some of the studies report seasonal occurrence of stroke, others indicate its absence ${ }^{25,26}$. These inconsistent findings may reflect geographical differences and regional climate effect, or differences in stroke type included in the studies. Our study showed monthly variations in stroke occurrence, with the peak occurrence in March and lowest occurrence in June.

Brain neoplasms are divided into primary and metastatic tumors, each accounting for about half of all brain tumors ${ }^{27}$. Although some previous reports suggested sex differences in the occurrence of primary brain tumors, a recent study by de Robles et al. indicated no statistically significant gender difference in the overall estimate of brain tumors ${ }^{27,28}$. The most common tumor found in our study was an unclassified tumor, suggesting that $\mathrm{CT}$ as an imaging technique was unable to characterize most of these tumors. For primary brain tumors, patient average age at onset is around 54 years, although age distribution may differ by tumor site and histologic type ${ }^{27}$. Our study showed the peak occurrence of brain tumors in patients aged 50-80 years.

This study had several limitations. It was a singlecenter study which included participants from one geographical region; as such, the results may not be widely representative. Patients with diagnostic assessment outside the ED and children were not included, therefore the prevalence of pathologic findings in the population could not be evaluated.

\section{Conclusion}

Computed tomography is commonly used to evaluate patients presenting to the ED with suspected intracranial disorders or head trauma. Early detection of pathologic CT findings in patients with head trauma, acute stroke or intracranial tumor may be critical for treatment decision. Our study found that men and elderly accounted for the greatest number of traumatic head injuries, thus being at the highest risk of the possible brain injury. Monthly variations in the number of stroke and head injuries may be related to seasonal differences, but further investigation is needed.

\section{References}

1. Feigin VLLC, Bennett DA, Barker-Collo SL, Parag V. Worldwide stroke incidence and early case fatality reported in 56 population-based studies: a systematic review. Lancet Neurol. 2009; 8:355-69. http://dx.doi.org/10.1016/S1474-4422(09)70025-0

2. Wintermark M, Sanelli PC, Albers GW, Bello JA, Derdeyn $\mathrm{CP}$, Hetts SW, et al. Imaging recommendations for acute stroke and transient ischemic attack patients: a joint statement by the American Society of Neuroradiology, the American College of Radiology and the Society of NeuroInterventional Surgery. AJNR Am J Neuroradiol. 2013;34(11):117-27. https://doi. org/10.3174/ajnr.A3690

3. Weiss AJ, Wier LM, Stocks C, Blanchard J. Overview of Emergency Department Visits in the United States, 2011. Statistical Brief \#174. Available from https://www.hcup-us.ahrq. gov/reports/statbriefs/sb174-Emergency-Department-VisitsOverview.pdf

4. Broder J, Warshauer DM. Increasing utilization of computed tomography in the adult emergency department, 2000-2005. Emerg Radiol. 2006;13(1):25-30. http://doi.org/10.1007/ s10140-006-0493-9

5. Larson DB, Johnson LW, Schnell BM, Salisbury SR, Forman HP. National trends in CT use in the emergency department: 1995-2007. Radiology. 2011;258(1):164-73. https://dx.doi. org/10.1148/radiol.10100640

6. Hussein W, Mullins PM, Alghamdi K, Sarani B, Pines JM. Trends in advanced computed tomography use for injured $\mathrm{pa}^{-}$ tients in United States emergency departments: 2007-2010. Acad Emerg Med. 2015;22(6):663-9. http://dx.doi.org/ 101111/acem.12684

7. Faul M, Xu L, Wald MM, Coronado VG. Traumatic brain injury in the United States: emergency department visits, hospitalizations, and deaths 2002-2006. Available from https://acquia-stage-nhtsa.dot.gov/sites/nhtsa.dot.gov/files/cdc_2010_ blue_book.pdf.

8. Christopher EG, Mark RZ. Emergency department visits for head trauma in the United States. BMC Emerg Med. 2016; 16:5. http://dx.doi.org/10.1186/s12873-016-0071-8

9. Rutland-Brown W, Langlois JA, Thomas KE, Xi YL. Incidence of traumatic brain injury in the United States, 2003. J Head Trauma Rehabil. 2006;21(6):544-8.

10. Tagliaferri F, Compagnone C, Korsic M, Servadei F, Kraus J. A systematic review of brain injury epidemiology in Europe. Acta Neurochir (Wien). 2006;148(3):255-68. https://doi.org/ 10.1007/s00701-005-0651-y

11. Frost RB, Farrer TJ, Primosch M, Hedges DW. Prevalence of traumatic brain injury in the general adult population: a metaanalysis. Neuroepidemiology. 2013;40(3):154-9. https://doi. org/10.1159/000343275 
12. Špero M, Bedek D, Kalousek M, Hat J, Rumboldt Z, Stuparić $\mathrm{N}$, et al. The value of brain CT scan in emergency service: a retrospective analysis Acta Clin Croat. 2004;43:75-87.

13. Tallon JM, Ackroyd-Stolarz S, Karim SA, Clarke DB. The epidemiology of surgically treated acute subdural and epidural hematomas in patients with head injuries: a population-based study. Can J Surg. 2008;51(5):339-45.

14. Monsef Kasmaei V, Asadi P, Zohrevandi B, Raouf MT. An epidemiologic study of traumatic brain injuries in emergency department. Emerg (Tehran). 2015;3(4):141-5.

15. Yu Hu, Hong Sun, Yanqing Yuan, Qiang Li, Siqing Huang, Shu Jiang, Kaili Liu, Chaohua Yang. Acute bilateral mass-occupying lesions in non-penetrating traumatic brain injury: a retrospective study. BMC Surg. 2015;15:6. https://doi.org/ 10.1186/1471-2482-15-6

16. Fu TS, Jing R, Fu WW, Cusimano MD. Epidemiological trends of traumatic brain injury identified in the emergency department in a publicly-insured population, 2002-2010. PLoS One. 2016;11(1):e0145469. https://doi.org/10.1371/ journal.pone.0145469

17. Asplund K, Karvanen J, Giampaoli S, Jousilahti P, Niemelä M, Broda G, et al. Relative risks for stroke by age, sex, and population based on follow-up of 18 European populations in Žthe MORGAM Project. Stroke. 2009;40(7):2319-26.https:// doi.org/10.1161/STROKEAHA.109.547869

18. Bamford J, Sandercock P, Dennis M, Warlow C, Jones L, $\mathrm{McPherson} \mathrm{K}$, et al. A prospective study of acute cerebrovascular disease in the community: the Oxfordshire Community Stroke Project 1981-86. 1. Methodology, demography and incident cases of first-ever stroke.J Neurol Neurosurg Psychiatry. 1988;51:1373-80.

19. European Registers of Stroke (EROS) Investigators, Heuschmann PU, Di Carlo A, Bejot Y, Rastenyte D, Ryglewicz D, et al. Incidence of stroke in Europe at the beginning of the $21^{\text {st }}$ century. Stroke. 2009;40(5):1557-63. https://doi.org/10.1161/ STROKEAHA.108.535088
20. Appelros P, Stegmayr B, Terént A. Sex differences in stroke epidemiology: a systematic review. Stroke. 2009;40(4):108290. https://doi.org/10.1161/STROKEAHA.108.540781

21. Barker-Collo S, Bennett DA, Krishnamurthi RV, Parmar P, Feigin VL, Naghavi M, et al. Sex differences in stroke incidence, prevalence, mortality and disability-adjusted life years: results from the Global Burden of Disease Study 2013. Neuroepidemiology. 2015;45(3):203-14. https://doi.org/10.1159/ 000441103

22. Sudlow CL, Warlow CP. Comparable studies of the incidence of stroke and its pathological types: results from an international collaboration. International Stroke Incidence Collaboration. Stroke. 1997;28(3):491-9, https://doi.org/10.1161/01. STR.28.3.491

23. Low RB, Bielory L, Qureshi AI, Dunn V, Stuhlmiller DF, Dickey DA. The relation of stroke admissions to recent weather, airborne allergens, air pollution, seasons, upper respiratory infections, and asthma incidence, September 11, 2001, and day of the week. Stroke. 2006;37(4):951-7. https://doi.org/ 10.1161/01.STR.0000214681.94680.66

24. Oberg AL, Ferguson JA, McIntyre LM, Horner RD. Incidence of stroke and season of the year: evidence of an association. Am J Epidemiol. 2000;152(6):558-64.

25. Ricci S, Celani MG, Vitali R, La Rosa F, Righetti E, Duca E. Diurnal and seasonal variations in the occurrence of stroke: a community-based study. Neuroepidemiology. 1992;11:59-64.

26. Alter M, Christoferson L, Resch J, Myers G, Ford J. Cerebrovascular disease: frequency and population selectivity in an upper midwestern community. Stroke. 1970;1(6):454-65.

27. Wrensch M, Minn Y, Chew T, Bondy M, Berger MS. Epidemiology of primary brain tumors: current concepts and review of the literature. Neuro Oncol. 2002;4(4):278-99.

28. de Robles P, Fiest KM, Frolkis AD, Pringsheim T, Atta C, St Germaine-Smith C, et al. The worldwide incidence and prevalence of primary brain tumors: a systematic review and metaanalysis. Neuro Oncol. 2015;17(6):776-83. https://doi.org/ 10.1093/neuonc/nou283 
Sažetak

ANALIZA VIŠESLOJNE KOMPJUTORIZIRANE TOMOGRAFIJE MOZGA U HITNOJ SLUŽBI

D. Zadravec, T. Greguric, M. Smoljan, M. Mustapić, G. Miličic, A. Jović, D. Rubil, D. Tomasović i V. Bašić Kes

Cilj ove studije bio je istražiti učestalost ozljeda glave, akutnog moždanog udara i tumora mozga iz nalaza kompjutorizirane tomografije (CT) dobivenih u hitnoj službi tijekom jedne godine. Jedan od ciljeva istraživanja bio je ispitati i potencijalni utjecaj godišnjeg doba izraženog u mjesečnim intervalima na pojavu traumatskih lezija glave, akutnog moždanog udara i tumora mozga. Radi se o retrospektivnom istraživanju u kojem smo koristili podatke iz bolničke elektroničke arhive za bolesnike koji su obrađivani u sklopu hitne službe bolnice. Ukupno je odraslim bolesnicima pregledanim u hitnoj službi učinjeno $3888 \mathrm{CT}$ pregleda glave, od čega su $1424 \mathrm{CT}$ nalaza ispunjavali ulazne kriterije za istraživanje. Od ukupnog broja učinjenih CT pregleda akutni moždani udar nađen je u 552 (14,19\%) bolesnika, trauma glave u 660 (16,97\%) bolesnika, a tumor mozga u $212(5,45 \%)$ bolesnika. Trauma glave je bila češća u muških bolesnika (N=465; 70,45\%) u odnosu na bolesnice $(\mathrm{N}=195 ; 29,54 \%)$. Akutni moždani udar bio je nešto češći u muškaraca nego u žena. Tumori mozga bili su češći u ženskih bolesnika. Postojale su mjesečne varijacije u broju dijagnosticiranih traumatskih lezija glave i moždanih udara. Ovo istraživanje je pokazalo da ozljede glave najčešće zadobivaju muškarci i starije osobe pa stoga imaju i najveći rizik za ozljede mozga.

Ključne riječi: Kompjutorizirana tomografja; Hitna služba u bolnici; Kraniocerebralne ozljede; Moždani udar; Moždani tumori 